\title{
The use of liver slices from the Cape vulture (Gyps coprotheres) to better understand the role of liver toxicity of Non-steroidal anti-inflammatory drugs (NSAIDs) in vultures
}

Emmanuel Oluwasegun Adawaren ${ }^{1}$, Lilian Mukandiwa ${ }^{1,2}$, Emmanuel Mfotie Njoya ${ }^{1}$, Lizette Bekker $^{1}$, Neil Duncan ${ }^{1}$, and Vinny Naidoo ${ }^{1,2 *}$

1- Department of Paraclinical Science, Faculty of Veterinary Science, University of Pretoria, South Africa.

2- Biomedical research Centre, Faculty of Veterinary Science, University of Pretoria, South Africa.

*Corresponding author: Emmanuel Oluwasegun Adawaren adawarenvet1@yahoo.com +27747749213.

Department of Paraclinical Science, Faculty of Veterinary Science, University of Pretoria, Soutpan Road 0110, Pretoria, South Africa

\section{Highlights}

- Liver slices cultures can be established from euthanized vulture.

- The vulture liver had a total lower protein content than for an animal of its size.

- While ex vivo metabolism resulted, no correlation to previous in vivo studies were present.

- All tested NSAIDs were toxic, including meloxicam which was likely due to the residence time.

- The results show that vultures liver slice cultures are a poor predictor of NSAID susceptibility. 


\section{Graphical abstract}

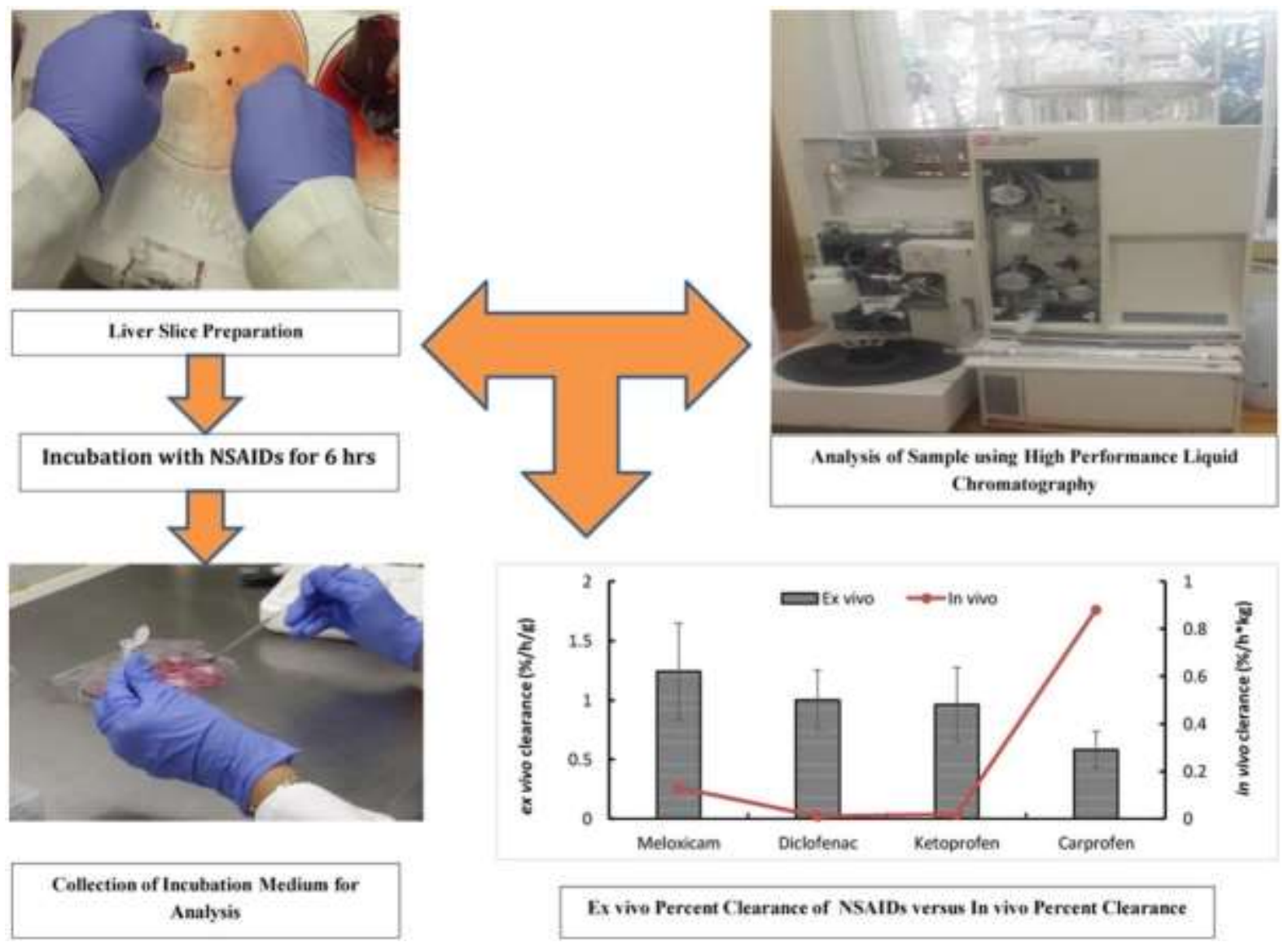

\section{Abstract}

Diclofenac, a non-steroidal anti-inflammatory drug (NSAID) was responsible for the death of millions of vultures on the Asian subcontinent, following the consumption of diclofenac contaminated carcasses. The aim of this research was to establish if liver slices could serve as an alternate means of predicting the toxicity of NSAIDs in Gyps vultures. The Cape vulture liver slices was prepared and incubated with four NSAIDs for $6 \mathrm{~h}$. A percent clearance of $1.0 \pm 0.253, \quad 0.58 \pm 0.153, \quad 0.961 \pm 0.312$ and $1.242 \pm 0.406\left(\% / h^{*} \mathrm{~g}\right)$ was attained for diclofenac, carprofen, ketoprofen and meloxicam respectively. Both meloxicam and diclofenac exerted toxic effects on the hepatic cells. Protein content indicated that the vulture tissue had lower enzyme levels than expected for an animal of its size. The poor distinction 
between the ex vivo hepatic percent clearance of meloxicam and diclofenac indicates that liver slices is not an ideal model to investigate NSAIDs toxicity in Cape vulture.

\section{Keywords}

Diclofenac; Meloxicam; Liver slices; Cape vulture; Percent clearance; Toxicity

\section{Introduction}

Vultures are large raptors that feed predominately on carrion, thereby playing an important role in cleaning the environment as well as mitigating the spread of infectious diseases from putrefying carcasses (Markandya et al., 2008, Vijaikumar et al., 2002). Unfortunately with the global decline in vulture population, carcasses end up rotting in the environment producing an unpleasant smells with increased pest numbers resulting in the spread of infectious diseases. Tlike anthrax, leptospirosis, brucellosis and tuberculosis (Markandya et al., 2008,Swan et al., 2006b). Globally, the population of this group of bird species has declined due to a multiple of threats from loss of habitat, direct persecution, poisoning (both malicious and intentional), electrocutions, muti trade and most recently from the exposure to diclofenac on the Asian subcontinent (Ogada et al., 2012,Angelov et al., 2013,Angelov et al., 2013, Virani et al., 2011,Boshoff et al., 2011,Boshoff et al., 2011,Sarans and Purohit, 2012,Sarans and Purohit, 2012,Oaks et al., 2004,MaMing and Xu, 2015,Naidoo et al., 2011,Naidoo et al., 2011,Naidoo et al., 2017). Of all these, the latter has received the most attention after three vulture species, the long-billed vulture (LBV) (Gyps indicus), the slender-billed vulture (SBV) (G. tenuirostris) and oriental white-backed vulture (OWBV) $(G$. bengalensis) in India, Pakistan and Nepal were brought to the brink of extinction, with a cumulative decline from 1990 to 2007 of 96.7 to $99.9 \%$ (Prakash et al., 2007). All three 
species are now listed as critically endangered by the International Union for the Conservation of Nature (IUCN) (Hilton-Taylor and Mittermeier, 2000).

At first the cause for the vulture deaths on the Asian subcontinent was unknown, with clinical signs of neck drooping, depression, elevated serum uric acid, and visceral gout lesion on the liver and kidney being the only signs (Oaks et al., 2004,Shultz et al., 2004,Green et al., 2004). After substantial investigation, the source of toxicity was eventually linked to residues of diclofenac present in the vulture food chain as a result of livestock being on palliative diclofenac treatment at the time of their death (Oaks et al., 2004,Shultz et al., 2004,Green et al., 2004). Diclofenac (2-[2-(2,6-dichlorophenyl amino) phenyl]acetic acid) is a non-steroidal anti-inflammatory drug (NSAID), developed in the late 1970s for the treatment of pain, fever and inflammatory conditions such as osteoarthritis, rheumatoid arthritis, and ankylosing spondylosis in humans (Scully et al., 1993,Burke et al., 2006). The drug also has merit in veterinary medicine for the management of livestock disease due to its analgesic and antiinflammatory properties. In India specifically, where there are large populations of livestock due to their religious significance, diclofenac was commonly used from a combination of its cost effectiveness, pharmacological effectivity and ease of acquisition as it could be acquired without veterinary prescription. This in combination with the absence of proper facilities for the disposal of dead animal's carcasses resulted in these carcasses being left out in the field to putrefy or to feed canine feeders. This practice over time contributed to a large number of vultures being exposed to toxic levels of diclofenac.

In an attempt to prevent the extinction of these species of vulture, the veterinary use of diclofenac was banned in India, Pakistan, Nepal, and most recently in Bangladesh (Prakash et al., 2007,Save, 2014). Efforts were also made into searching for alternative drugs such as meloxicam (Swan et al., 2006a), as well as to establish viable breeding colony of birds that would later be introduced when the threat of diclofenac was removed (Save, 2014,Bowden et 
al., 2012). In addition, further research was undertaken to characterise the mechanism of diclofenac toxicity in the Asian Gyps. From pharmacological studies, the pharmacokinetics of diclofenac was established in numerous species. Of the numerous studies undertaken, the two specific studies undertaken in South Africa with two vulture species, showed them to be highly susceptible to diclofenac toxicity, with the toxicity being associated with an extended elimination half-life of $12.24 \mathrm{~h}$ in the Cape vulture (Gyps coprotheres) and 16.78 hours in African white-backed vulture (Gyps africanus) (Naidoo et al., 2009). The determined half-life was in marked contrast to the Pied crow (Corvus albus), which showed no signs of toxicity, with the diclofenac being barely detectable in the plasma with a half-life of elimination estimated to be in the region of 2.33 hours (Naidoo et al., 2011). Furthermore, $25 \mathrm{mg} / \mathrm{kg}$ of diclofenac administered to Turkey vulture (Cathates aura) showed no sign of toxicity and had an elimination half-life of 6 hours in (Rattner et al., 2008). This led to the speculation that toxicity in the Vulture was linked to capacity specific metabolism.

From a pharmacological point of view, the half-life of a drug is dependent on the rate of absorption, the volume of distribution, metabolism and excretion (clearance) (de Graaf et al 2006; De Kanter et al 2004; de Graaf et al 2010). A drug with a high clearance rate will have a short half-life, which is highly dependent on the kidney as well as other organs such as the liver, lungs and gastrointestinal tract. Clearance of a drug is also affected by the volume of distribution, amount bound to plasma protein, blood flow to the excretory organs, rate of biotransformation and pharmacogenomic capability of the metabolizing enzymes (phase 1 or phase 2 enzymes) (Kasperek et al., 2015). However, in contrast the clearance of drug in ex vivo model such as liver slices, specialised cell lines (for example renal or hepatocytes), cytosolic (S9 fraction) or microsomal fraction would depend on the functionality of the metabolizing enzymes (Cytochrome P450 enzymes). Variations in the functionality of these enzymes determine the differences observed with drug clearance among animal species 
(Watanabe et al., 2013, Yan and Caldwell, 2001). This makes liver slice models an attractive model for the evaluation of toxicity as a direct effect of metabolic capacity or limitation can be ascertained.

(Naidoo et al., 2011)For this study the ex vivo half-life of diclofenac was determined in a liver slice model as a means to evaluate metabolism in the absence of external factors. For comparative purposes the study included meloxicam, ketoprofen and carprofen as they have been shown to be toxic in old world vultures with the exception of meloxicam, together with all having different half-lives of elimination (Naidoo et al., 2017,Naidoo et al., 2010,Naidoo et al., 2008). The latter drugs were thus used to evaluate the appropriateness of the model in relation to differential metabolic rates. To ensure metabolism was not related to harvest site specific variation in enzyme content, microsomal protein content was determined for equalisation. The latter also allowed for inter species comparison of total protein content as a surrogate in determining differences in enzyme content.

Tissue slices are a viable multicellular explant of tissue that can be cultured ex vivo in suitable culture medium under certain conditions. They consist of all cell types with intercellular and cellular matrix interactions remaining intact. Tissue slices have been prepared from the liver, heart, kidney, lungs, spleen, intestine, brain, prostrate and several tumours (de Graaf et al., 2010,Graaf et al., 2007,de Graaf et al., 2006). They have been used to study biochemical functions such as endogenous metabolism, biotransformation and the induction and transport of drugs and other xenobiotics. They are also used in toxicological studies as well as efficacy studies of drugs on diseased tissues. In addition, tissue slices have been used to study ischaemia/reperfusion damage and determine the specificity of viruses as carriers for gene therapy agents (de Graaf et al., 2010,t Hart et al., 2005,Langdale et al., 2003). Based on these previous reports, the current study intends to establish the usage of liver tissue slices as a model to evaluate the toxicity of NSAIDs in vultures. 


\section{Materials and Methods}

\subsection{Materials}

Sodium pentobarbital $\left(\right.$ Euthapent $\left.^{\circledR}\right)$, Williams medium E (WME), containing Lglutamine, gentamicin sulphate, amphotericin $\beta$, D-glucose monohydrate, sodium hydroxide $(\mathrm{NaOH}$ ), formalin $4 \%$ (formaldehyde solution 3.8-4.2\% v/v), diclofenac sodium, ketoprofen, meloxicam and carprofen, bovine serum albumin, and Bradford Reagent were manufactured by Sigma-Aldrich (St Louis, MO, USA). A $6 \mathrm{~mm}$ biopsy punch was supplied by Lakato (Johannesburg, South Africa). Cell culture multi-well plates, (96- and 6 well), cryogenic vial storage boxes, $50 \mathrm{ml}$ centrifuge tubes and $2 \mathrm{ml}$ cryogenic tubes (Greiner Bio-One, Frickenhausen, GE) and HPLC grade methanol and acetonitrile (Merck, Darmstadt, GE) were used. Carbogen gas (5\% CO2/ 95\% O2) was obtained from Afrox (Johannesburg, South Africa). Equipment comprised of a BioTek Synergy HT spectrophotometer (BioTek, Winooski, VT, USA), a Beckman Allegra TM FX-22R centrifuge (Beckman Coulter, Palo Alto, CA, USA), a Beckman XL 90 ultracentrifuge equipped with a Ti50 rotor (Beckman Coulter, Palo Alto, CA, USA), and a Beckman System Gold high performance liquid chromatograph (HPLC), equipped with a 126 Solvent Module, a 168 PDA detector, a 508 autosampler, and 32 Karat 8.0 software (Beckman Coulter, Fullerton, CA, USA). Chromatographic separation was achieved with a Thermo Scientific BDS HYPERSIL C18 HPLC column (Thermo Scientific, Runcorn, UK), dimensions: 250mm X 4.6mm X 5 $\mu \mathrm{m}$.

\subsection{Methods}

\subsubsection{Preparation of liver tissue slices}

The use of vulture liver for this study was approved by the Animal Ethics Committee (AEC) of the University of Pretoria, South Africa, with project number V093-15. A two-year old male cape vulture with the history of lameness of the left leg (for eight weeks) was 
brought to the University of Pretoria Biomedical Research Centre (UPBRC) for euthanasia. The bird was otherwise in good health. The bird was euthanized by intravenous injection of pentobarbital. The dead bird was transferred into the laminar hood to aseptically remove the liver thus, briefly, the abdominal cavity was opened, the ribs were severed and the breast bone raised and maintained in this position to permit access to the liver. The liver was excised from the abdominal cavity and manually sliced with modification to the method of Graaf et al (2010) as described below.

The William medium E (WME) was prepared by mixing $1.375 \mathrm{~g}$ of D-glucose monohydrate with $500 \mu \mathrm{L}$ gentamicin $(50 \mathrm{mg} / \mathrm{mL})$, and $5 \mu \mathrm{L}$ of amphotericin $\beta(250 \mu \mathrm{g} / \mathrm{mL})$ to $500 \mathrm{~mL}$ of commercial WME (containing L-glutamine). The resulting solution was oxygenated with $95 \%$ oxygen and $5 \%$ carbon dioxide and stored for 24 hours at $4^{\circ} \mathrm{C}$ prior to liver slices incubation. The freshly excised liver was transferred into a sterile sample bottle containing ice-cold WME solution on ice under sterile condition in a laminar hood. The liver was cut into segments using a surgical blade and the surface kept wet by pouring WME solution on it. Cores were made by pressing a biopsy punch ( $6 \mathrm{~mm}$ diameter) perpendicularly into the tissue until it reached the bottom of the petri dish to produce a $5 \mathrm{~mm}$ tissue core. The cores were transferred to a petri dish containing ice cold WME solution on ice using a spatula and the medium was oxygenated continuously. The tissue cores were later cut into thin slices of $5 \mathrm{~mm}$ diameter width. The tissue slices were then transferred into pre-weighed vials of WME solution and then reweighed to get the exact weight (ranging from 5.6 to $8.2 \mathrm{mg}$ ) of the tissue slice. Sliced liver tissues were transferred into fresh ice-cold WME solution continuously bubbled with $95 \%$ oxygen and $5 \% \mathrm{CO}_{2}$ and placed on ice prior to tissue slice assay. Individual liver slices were incubated in 6 well plates filled with William medium E (3.2 $\mathrm{ml} /$ well) and supplemented with glucose $(25 \mu \mathrm{M})$, and gentamicin $(50 \mu \mathrm{g} / \mathrm{ml})$. The medium was pre-warmed inside an incubator at $37^{\circ} \mathrm{C}$ and quickly transferred into the 6 well 
plates measuring $3.2 \mathrm{ml}$ using a sterile pipette under the laminar hood. The plates were placed in an incubator and shaken every 10 minutes to ensure slices are continuously submerged in the medium at $37{ }^{0} \mathrm{C}$ under constant flow of humidified $95 \% \mathrm{O}_{2} / 5 \% \mathrm{CO}_{2}$. The tissue slices were allowed 3 hours to equilibrate prior to the incubation of the slices with the drugs.

\subsubsection{Drug treatment and sample preparation}

The NSAIDs were added into the incubation medium using an optimal concentration $(1 \mu \mathrm{M})$, that was considered to be non-cytotoxic. This concentration was based on previous dose-determination studies using chicken and mouse liver slices for which no signs of toxicity were evident (results not shown). The positive control groups contained NSAIDs and the incubation medium without liver slices while the negative control groups contained tissue slices and incubation medium. Liver tissue slices were incubated with NSAIDs for 6 hours. Following addition of the specific NSAIDs, aliquots of the medium $(250 \mu \mathrm{L})$ were collected at $0,1,2,3,4,5$ and 6 hours respectively. Aliquots of the sampled medium $(250 \mu \mathrm{L})$ were mixed with $250 \mu \mathrm{L}$ ice-cold methanol and stored at $-80^{\circ} \mathrm{C}$ until analysis. Diclofenac-exposed samples were centrifuged at $8000 \mathrm{x} g$ for 10 minutes at $4{ }^{0} \mathrm{C}$ and mixed with equal amount of the mobile phase and acidified with $2 \mathrm{M} \mathrm{HCl}$ at a ratio of 1:100. Carprofen, meloxicam and ketoprofen were quantified without any prior sample preparation as the case of diclofenac (Bort et al., 1999,De Kanter et al., 2004).

\subsubsection{High performance liquid chromatography (HPLC) analysis of collected samples}

The samples were analysed for depletion of NSAIDs using high performance liquid chromatography (HPLC). For the separation of the various drug compounds, an isocratic method was used comprising of two mobile phases namely sodium dihydrogen phosphate (A) (pH 4.85-4.89) and acetonitrile (B). For the diclofenac analyses, the mobile phases were

mixed at the ratio of 42.5 (A): 57.5 (B) while the remaining NSAIDs were analysed at a 
mixture of $60(\mathrm{~A}): 40(\mathrm{~B})$. Fifty microliter $(50 \mu \mathrm{L})$ of each sample was injected onto the HPLC column at $1000 \mu \mathrm{L} / \mathrm{min}$ with a total runtime of 8 minutes. The detection of the NSAIDs was undertaken at $275 \mathrm{~nm}$ (Naidoo et al., 2007).

\subsection{Evaluation of tissue slice viability}

The basal cellular viability of cultured liver slices are investigated using parameters such as ATP content, $\mathrm{Na}^{+} / \mathrm{K}^{+}$ATP-ase activity and integrity of morphology. The most important of these parameters is the morphology of tissue slice with the demerit of using skilled personnel to interpret the results (de Graaf et al 2010). Therefore, the viability of liver slices were evaluated histomorphologically for the untreated and treated slices preincubated in William Medium E without drugs for 3 hours and those exposed to NSAIDs for 6 hours. Liver slices were fixed in formalin and embedded in paraffin wax. Wax blocks were subsequent cut and stained with Haematoxylin and Eosin for microscopic evaluation.

\subsection{Protein determination of liver slices}

The protein content of Cape vulture liver slices was used as suitable surrogate in allometric comparison to other animal species. The protein content of pre-weighed tissue slices was determined with the Bradford reagent dye and a bovine serum albumin (BSA) standard curve using a 96 well method. Liver slices were homogenised in $0.1 \mathrm{M} \mathrm{NaOH}$ under ice. The protein content of the slices was determined by a spectrophotometer at $595 \mathrm{~nm}$ wavelength. A stock solution of BSA $(2 \mathrm{mg} / \mathrm{mL})$ was serially diluted to a range of $1-0.1$ $\mathrm{mg} / \mathrm{mL}$ using $0.1 \mathrm{M} \mathrm{NaOH}$ buffer. The homogenised liver slices were diluted to a stock concentration of $10 \mathrm{mg} / \mathrm{mL}$. In addition, $100 \mu \mathrm{L}$ of the stock samples were diluted with 900 $\mu \mathrm{L}$ of $0.1 \mathrm{M} \mathrm{NaOH}$ to give a working concentration of $1 \mathrm{mg} / \mathrm{mL}$. Five microliters of the BSA and homogenised liver slices were placed into different wells in triplicate and $250 \mu \mathrm{L}$ of the Bradford reagent added to each well. To the blank wells, $5 \mu \mathrm{L}$ of $0.1 \mathrm{M} \mathrm{NaOH}$ was placed 
into them, as well as $250 \mu \mathrm{L}$ of the Bradford Reagent. After the addition of the Bradford Reagent, the samples were mixed on a shaker for 30 seconds and allowed to incubate at room temperature for 5-45 minutes. The absorbance of samples was measured at $595 \mathrm{~nm}$. The protein concentration of the homogenised liver slices was determined by plotting the net absorbance versus the protein concentration of the standard BSA and comparing the net absorbance values against the standard curve (Bradford, 1976).

\subsection{Preparation of microsomal liver fraction}

Microsomes from Cape vulture liver slices were compared to other bird and mammalian species to investigate the reduced metabolic capability of old world vultures to NSAIDs. Ten (10) liver slices stored in cyrotubes at $-80{ }^{0} \mathrm{C}$, weighing between $22.6-55.8 \mathrm{mg}$ were homogenised in $0.15 \mathrm{M} \mathrm{KCl}$; 0.02 M HEPES; pH 7.5 under ice. The homogenised liver samples were transferred into Beckman $10.4 \mathrm{~mL}$ polycarbonated ultracentrifuge tubes, and loaded into the Beckman Allegra TM FX-22R centrifuge and centrifuged at $10,000 \mathrm{x} g$ for 20 minutes at $2^{\circ} \mathrm{C}$. After centrifugation, the supernatant was carefully transferred into another clean ultracentrifuge tube to avoid the transfer of fat along with the supernatant. The supernatant from the first spin was properly balanced using homogenising buffer on a balance scale and loaded into the Beckman XL90 ultracentrifuge. The samples were centrifuged for 60 minutes at $100,000 \times g$ at $2^{\circ} \mathrm{C}$. Hereafter, the supernatant was discarded and the tube cleaned to remove fat particles. The microsomal pellets at the bottom of the ultracentrifuge tube was homogenized using the homogenizer pestle with the homogenizing buffer in the same ultracentrifuge tube, and centrifuged for the second time as described above. After, a third centrifuge, the supernatant was discarded and the tube cleaned to get rid of fat particles after which the microsomal pellets were resuspended in $0.3 \mathrm{~mL}$ of resuspension buffer $(0.05$ $\mathrm{M}$ tris; $1 \mathrm{mM}$ EDTA; $20 \%$ glycerol; $\mathrm{pH} 7.4)$, transferred into a cryotube and stored at $-80^{\circ} \mathrm{C}$ 
for further analysis (Papp et al., 2005,Martinez and Alonso, 2014). The protein content of the liver microsomal fractions was determined using the Bradford method as above.

\subsection{Statistical analysis of results}

The percent clearance per hour $(\% \mathrm{CL} / \mathrm{h})$ of the non-steroidal anti-inflammatory drugs were calculated by subtracting the concentration of the NSAIDs remaining after six hours of incubation in WME from the initial percent concentration of 100 divided by six hours of incubation as shown in equation 1(Kumar et al., 2002).

$$
\% \mathrm{CL} / \mathrm{h}=\frac{A-B}{C} \quad---------- \text { Equation } 1
$$

Where $\% \mathrm{CL} / \mathrm{h}$ is the percent clearance of NSAID per hour, A is NSAID initial percent concentration of $100, \mathrm{~B}$ is the NSAID concentration in percentage remaining after six hours of incubation and $\mathrm{C}$ is the entire time of incubation of 6 hours. Clearance was subsequently corrected by the quantity of protein per slice (see below). Difference in the ex vivo clearance of NSAIDs used in this study was determined by means of a one way analysis of variance (ANOVA) using GraphPad Prism 6.0 (Prism, 2014). Results were considered to be significant when $p<0.05$. (Bradford, 1976)(Papp et al., 2005,Martinez and Alonso, 2014)

\subsection{Allometric scaling}

The protein content of the Cape vulture liver was scaled to reported protein content of other mammal species using the liver weight of these species and their protein content $(\mathrm{mg} / \mathrm{g}$ liver) (Hunter and Isaza, 2008,Cox et al., 2004,Mahmood, 2007,Riviere et al., 1997). The weight of the different animal species, weight of the liver and protein content of the liver was obtained from published articles and compared to the weight of the liver and bird used for this study. The best fit equation was subsequently obtained from the logarithmic conversion of both tissue weight and protein content. The total protein content of the liver (mg) was 
obtained by multiplying the weight of the liver $(\mathrm{g})$ with the protein content (mg/g liver) and the logarithm of the liver weight and total protein content.

\section{Results}

\subsection{Percent clearance of NSAIDs after incubation with liver tissue slices}

The analytical method used for the quantification of NSAIDs in Cape liver slices was fully validated prior to analysis of the incubation media samples. The following validation results were obtained (table 1). In all cases the method showed good linearity (>99\%). The limit of quantification was $0.5 \mu \mathrm{M}$ for meloxicam, ketoprofen and carprofen; and $0.25 \mu \mathrm{M}$ for diclofenac. The positive control groups showed a constant amount of NSAIDs over the entire incubation period.

Table 1: Validation of the analytical method

\begin{tabular}{|l|l|l|l|l|}
\hline Parameter & Diclofenac & Meloxicam & Ketoprofen & Carprofen \\
\hline $\begin{array}{l}\text { Best Fit } \\
\text { Equation }\end{array}$ & $\mathrm{Y}=26122 \mathrm{x}+1856.7$ & $\mathrm{Y}=30749 \mathrm{x}-1135.3$ & $\mathrm{Y}=25189 \mathrm{x}-1361.4$ & $\mathrm{Y}=14919 \mathrm{x}-530.46$ \\
\hline $\begin{array}{l}\text { Goodness of } \\
\text { fit }\end{array}$ & $\mathrm{R}^{2}=0.9996$ & $\mathrm{R}^{2}=0.9989$ & $\mathrm{R}^{2}=0.9974$ & $\mathrm{R}^{2}=0.9988$ \\
\hline LOD $(\mu \mathrm{M})$ & 0.0625 & 0.125 & 0.125 & 0.0625 \\
\hline \begin{tabular}{l} 
LOQ $(\mu \mathrm{M})$ \\
\hline $\begin{array}{l}\text { Retention } \\
\text { Time (hour) }\end{array}$
\end{tabular} & 0.25 & 0.5 & 0.5 & 0.5 \\
\hline
\end{tabular}

The ex vivo percent clearance of diclofenac, meloxicam, ketoprofen and carprofen after incubation for 6 hours in Cape vulture liver slices in comparison to published in vivo clearance of the same drug in Cape vulture are presented in Fig. 1. Following correction for protein content, the corrected percent clearance and standard error of the four non-steroidal anti-inflammatory drugs was $1.0 \pm 0.253\left(\% / h^{*} \mathrm{~g}\right), 0.582 \pm 0.153(\% / \mathrm{h} * \mathrm{~g}), 0.961 \pm 0.312\left(\% / \mathrm{h}^{*} \mathrm{~g}\right)$ and $1.242 \pm 0.406\left(\% / h^{*} \mathrm{~g}\right)$ for diclofenac, carprofen, ketoprofen and meloxicam respectively. In general, the degree of ex vivo clearance was almost the same for meloxicam and 
diclofenac, followed by ketoprofen and lastly by carprofen. No statistical differences were observed between the samples after statistical analysis $(\mathrm{p}=0.5043)$.

Fig.1. Ex vivo liver slices percent clearance of meloxicam, diclofenac, ketoprofen and carprofen $(1.242 \pm 0.406 \% / \mathrm{h} * \mathrm{~g}, 1.0 \pm 0.253 \% / \mathrm{h} * \mathrm{~g}, 0.961 \pm 0.312 \% / \mathrm{h} * \mathrm{~g}$ and $0.582 \pm 0.153 \% / \mathrm{h} * \mathrm{~g})$ in comparison to in vivo clearance $(0.13 \mathrm{~L} / \mathrm{h} * \mathrm{~kg}, 0.01-0.02 \mathrm{~L} / \mathrm{h} * \mathrm{~kg}, 0.02 \mathrm{~L} / \mathrm{h} * \mathrm{~kg}$ and $0.88 \mathrm{~L} / \mathrm{h} * \mathrm{~kg})$ of same drugs in Cape vulture (Naidoo et al. 2010, Naidoo et al. 2008, Naidoo et al. 2009, Fourie 2015).

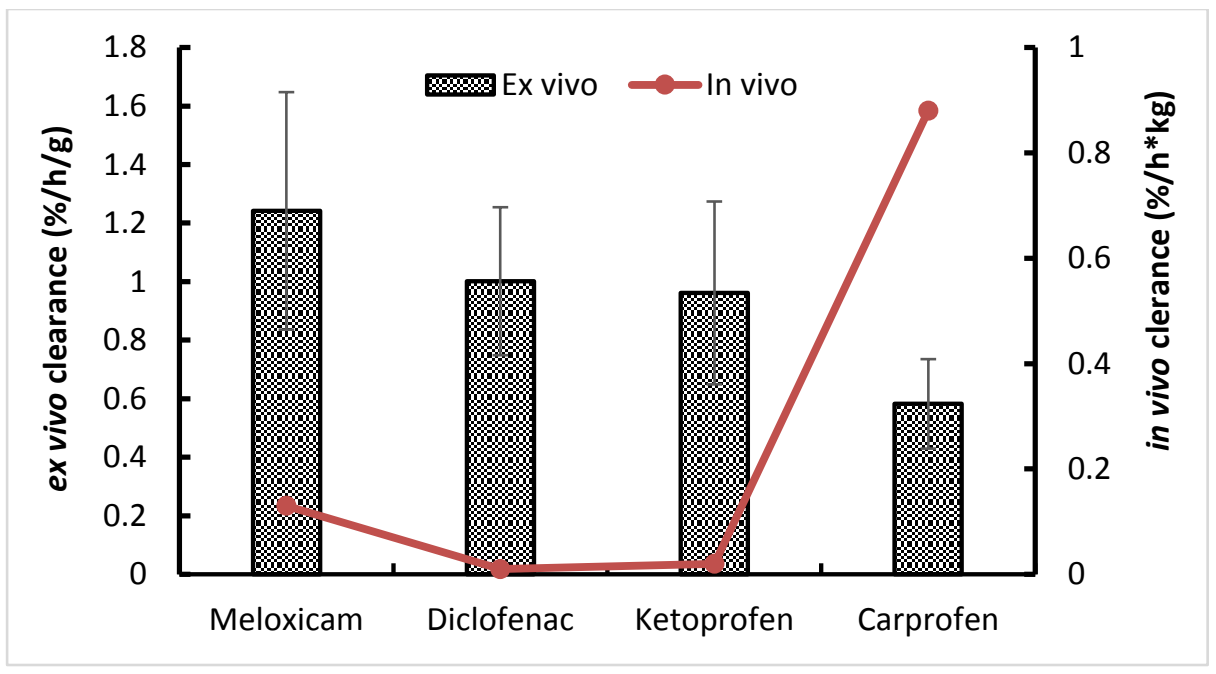

To determine the validity of the ex vivo clearance, the percent clearance from the liver slices was compared to their corresponding in vivo clearance of diclofenac sodium, carprofen, ketoprofen and meloxicam as presented in Fig.1. The ex vivo metabolism of the drugs did not clearly predict the high in vivo clearance of meloxicam in comparison to diclofenac and ketoprofen with the exception of carprofen which was reported to have a high clearance $(0.88$ $\mathrm{L} / \mathrm{h} * \mathrm{~kg}$ ) in the Cape vulture but in the African white-backed vulture a low clearance of 0.015 L/kg (Naidoo et al., 2017,Fourie, 2015). A trend for faster clearance was however evident for meloxicam in comparison to the other drugs. The clearance of carprofen appeared to be completely non-predictable.

\subsection{Histomorphological viability of liver slices}

The non-toxic concentration of $1 \mu \mathrm{M}$ NSAIDs were validated prior to the commencement of the study using liver slices incubated with the drugs from chicken and 
mouse. The histomorphological features of the liver slices of chicken and mouse had a normal nuclear structure with no sign of toxicity.

Following the termination of the experiment, the tissue slices were histologically evaluated (Fig.2). The tissue from the control group and those exposed to media showed no signs of toxicity with all the hepatocytes appearing healthy with normal nuclear structure (Fig.2-A and B). For the tissues exposed to the NSAIDs, the slices showed morphological lesions of toxicity, characterised as cytoplasmic vacuolation, nuclear shrinkage, nuclear basophilia and loss of internal structure (Fig.2-C). In addition, the slices exposed to meloxicam, showed fragmentation of the hepatic cords, cytoplasmic eosinophilia, nuclear pkynosis and karyorrhexis (Fig.2-D); while the carprofen slices at $1 \mu \mathrm{M}$ showed cytoplasmic vacuolation, loss of internal cytoplasmic structures, nuclear pkynosis and nuclear karyorrhexis (Fig.2-E). Finally, slices exposed to ketoprofen showed cytoplasmic vacuolation, nuclear pkynosis, nuclear karyorrhexis and cytoplasmic eosinophilia (Fig.2-F).

Fig.2. Light microscope photographs of liver slices of Cape vulture treated with NSAIDs (H\&E).

A. Control. H: hepatocyte; N: nucleus of hepatocytes.

B. Liver slice in William's medium E only for 6 hours. H: hepatocyte; N: nucleus of hepatocytes.

C. Liver slice incubated with diclofenac (6 hours). V: vacuolation; SN: pkynosis of nucleus; TLN: total loss of nucleus.

D. Liver slice incubated with meloxicam (6 hours). V: vacuolation; EN: eosinophilic nucleus; KN: karyorrhexis of nucleus; PN: pkynosis of nucleus.

E. Liver slice incubated with carprofen (6 hours). V: vacuolation; KN: karyorrhexis of nucleus; PN: pkynosis of nucleus.

F. Liver slice incubated with ketoprofen (6 hours). V: vacuolation; EN: eosinophilic nucleus; KN: karyorrhexis of nucleus; PN: pkynosis of nucleus. 


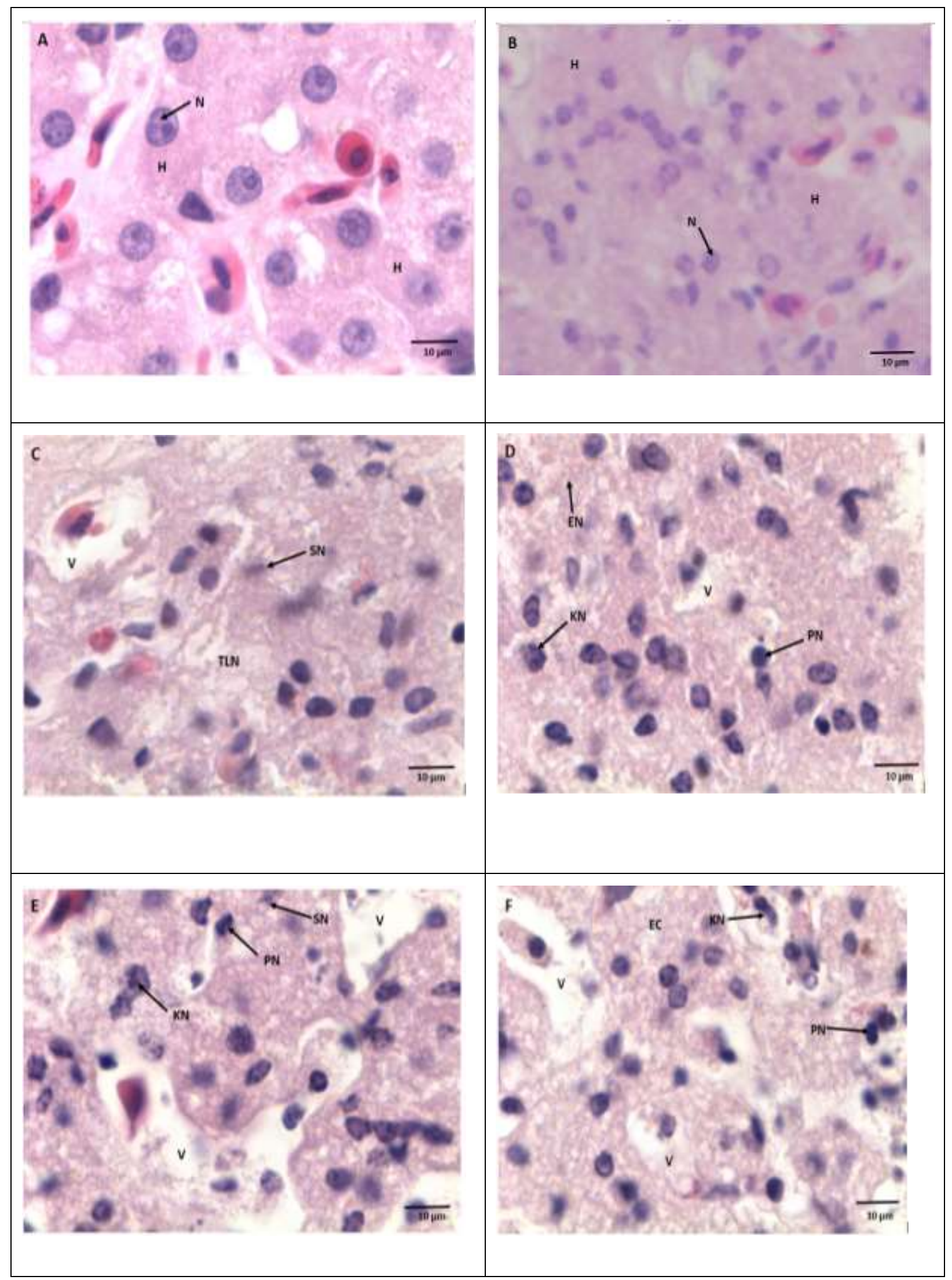




\subsection{Allometric scaling of liver protein}

The total liver protein content of the Cape vulture was $3325 \mathrm{mg} / \mathrm{g}$ liver, obtained by multiplying the liver weight of the Cape vulture (133 g) and average protein content of the whole liver slices $(25 \mathrm{mg}$ ). For the allometric scaling the liver weights from humans, dogs, rabbits, rats, and mice used in the study are presented in Table 2, while the protein content of the listed species are presented on a double logarithmic plot in Figure 4. For the latter, the best fit equation is $0.9604 \mathrm{x}+2.0975$ with a goodness of fit of 0.99 . Based on the equation for animal of the size of the study vulture, one would have expected a liver protein content of $13716.62 \mathrm{mg} / \mathrm{g}$ liver. Thus based on weight of the animal, the actual liver protein content was $24 \%$ lower than expected.

Table 2: Total liver protein content $(\mathrm{mg})$ of different species of animals

\begin{tabular}{|c|c|c|c|c|c|c|}
\hline Species & $\begin{array}{c}\text { Weight of } \\
\text { animal (kg) }\end{array}$ & $\begin{array}{l}\text { Weight of } \\
\text { liver }(g)\end{array}$ & $\begin{array}{l}\text { Logarithm of } \\
\text { liver weight }\end{array}$ & $\begin{array}{l}\text { Total protein } \\
\text { content of } \\
\text { liver }(\mathrm{mg})\end{array}$ & $\begin{array}{c}\text { Protein } \\
\text { content }(\mathrm{mg} / \mathrm{g} \\
\text { liver) }\end{array}$ & $\begin{array}{l}\text { Logarithm of } \\
\text { total protein } \\
\text { content }\end{array}$ \\
\hline Human $^{\mathrm{e}}$ & 62 & $1350^{\mathrm{e}}$ & 3.13 & 121500 & $90 \pm 17^{a}$ & 5.08 \\
\hline $\operatorname{Dog}^{a}$ & 17.5 & 349.2 & 2.54 & 35967.6 & $103 \pm 6^{a}$ & 4.56 \\
\hline Rabbit $^{\mathrm{a}}$ & 1.3 & $84.3^{\mathrm{d}}$ & 1.93 & 9188.7 & $109 \pm 9^{a}$ & 3.96 \\
\hline Rat $^{b}$ & 0.28 & $10.76^{b}$ & 1.03 & 1204.56 & $112 \pm 10^{\mathrm{a}}$ & 3.08 \\
\hline Mouse $^{c}$ & 0.02 & $6.1^{c}$ & 0.79 & 701.04 & $115 \pm 7^{\mathrm{a}}$ & 2.85 \\
\hline $\begin{array}{c}\text { Cape } \\
\text { Vulture } \\
\end{array}$ & 8.7 & 133 & 2.12 & 3325 & $25 \pm 1.7$ & 3.52 \\
\hline
\end{tabular}

a(Sohlenius-Sternbeck 2006), b(Piao, Liu \& Xie 2013), ${ }^{\mathrm{c}}\left(\right.$ Kendall et al. 2014) ${ }^{\mathrm{d}}($ Brown, Pearce \& Van Allen 1925) 
Fig. 3: The allometric scale of liver protein from human, dog, rabbit, rat, mouse and Cape vulture.

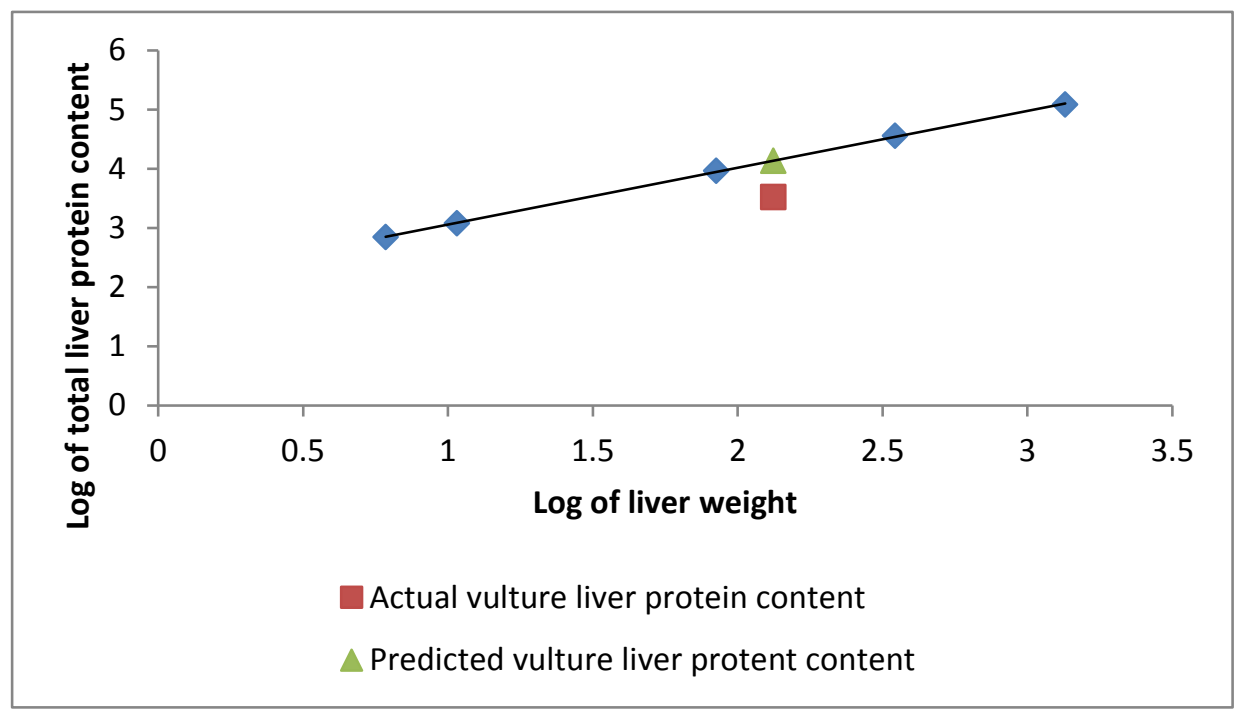

\section{Discussion}

It has been widely accepted that old world vultures are highly sensitive to the toxic effects of various NSAIDs, with the exception of meloxicam for an unknown reason (Oaks et al 2004; Swan et al 2006; Naidoo et al 2007; Naidoo et al 2010; Naidoo et al 2011). While the mechanism behind toxicity remains elusive, various pharmacokinetic studies have shown that the faster the clearance, the lower the toxic potential of the NSAIDs (Naidoo et al 2011). From previous studies in Gyps coprotheres, vulture safe meloxicam at a dose of $2 \mathrm{mg} / \mathrm{kg}$ was characterised by a half-life of elimination of $0.42 \pm 0.1$ hour and clearance of $0.13 \pm 0.00$ $\mathrm{L} / \mathrm{h} * \mathrm{~kg}$, while diclofenac at the dose of $0.8 \mathrm{mg} / \mathrm{kg}$ had a longer elimination half-life of 12.24 \pm 0.99 hours and a clearance of $0.01 \pm 0.006 \mathrm{~L} / \mathrm{h}^{*} \mathrm{~kg}$ (Naidoo et al., 2009,Naidoo et al., 2008). The same trend was seen with toxic doses of ketoprofen at $5 \mathrm{mg} / \mathrm{kg}$ which had a halflife of elimination of $7.38 \pm 1.72$ hours and a clearance of $0.02 \pm 0.01 \mathrm{~L} / \mathrm{h} * \mathrm{~kg}$. Carprofen had a longer half-life of elimination of $13.26 \pm 5.08$ hours and a high clearance of $0.88 \pm 0.85$ L/h*kg (Naidoo et al., 2011,Naidoo et al., 2010,Naidoo et al., 2010). This raised the question as to why the meloxicam was so rapidly cleared in comparison to the other two drugs. From 
pharmacokinetic theory, the rapid clearance may result from rapid biotransformation and/or rapid excretion of the unchanged molecule. Of these two, both are likely based on information available from other species, albeit mammalian.

In the majority of mammalian species meloxicam is rapidly metabolised and excreted by the kidneys, as 5'-hydroxymethyl and 5'-carboxymethyl metabolites. In mice, $60-65 \%$ of the metabolites are excreted through the urine (5'-hydroxymethyl metabolites (51\%), 5'carboxymethyl metabolites (4.5\%) and parent drug (0.2\%)), while $35-40 \%$ are eliminated via the faeces in the rat, renal excretion accounts for $70 \%$ of meloxicam elimination (5'carboxymethyl metabolite (30\%), 5'-hydroxymethyl metabolite (40\%) and parent drug $(0.2 \%))$; while in the mini-pig, 5'-hydroxymethyl metabolite accounts for $50 \%$ of the metabolites in the urine, while 5'-carboxylmethyl metabolites is $10 \%$. In addition, in the Baboon, $4 \%$ of the parent drug is found in the urine while $75 \%$ of the other metabolites are found in the urine (Busch et al., 1998). The only species that appears to be different is the cat, which shows a high degree of excretion of unchanged drug, with up to $50 \%$ of the administered dose being excreted unchanged in the bile. At present it has been suggested that latter may result from the cat's inability to glucuronide drugs in comparison to other animal species (Lascelles et al., 2007,Grudé et al., 2010)

Despite the difference in the manner of clearance, the cat and dog (5-hydroxymethyl and 5'carboxymethyl metabolites) has similar half-lives of excretion at 15 and 12 hours respectively. This would indicate that as a drug, meloxicam is still well excreted in the presence of poor or deficient metabolism.

The aim of this study was to establish if there was a clear difference in the metabolism of diclofenac, meloxicam, carprofen and ketoprofen under ex vivo conditions, in the absence of possible influence from other pharmacokinetic factors such as blood supply and the excretion of the non-metabolized drug. The drugs selected were based on previous evidence 
of toxicity (diclofenac, carprofen and ketoprofen) or safety (meloxicam) of the specific drugs in old world vulture species and the in vivo pharmacokinetic information available. The in vitro clearance of tissue slices has previously been used by various researchers to predict the in vivo clearance of different drug models (De Kanter et al., 2004,Kumar et al., 2002,Houston, 1994,Scott et al., 2011,Rane et al., 1977). The theory behind the extrapolation of in vivo clearance from in vitro data is based on the determination of the intrinsic clearance of the drug, which measures liver enzyme activity not influenced by other physiological determinant of liver clearance such as hepatic blood flow or drug binding within the haemoproteins (Houston, 1994).

From the results of the hepatic slice culture, the positive control group showed constant level of the drugs for the entire incubation period of 6 hour, indicating nondegradation of the drugs in the incubation medium. Furthermore, all the drugs showed a nonsignificantly different rate of clearance for which the following trend was evident: meloxicam $>$ diclofenac $=$ ketoprofen $>$ carprofen, with relatively poor correlation to the in vivo clearance. These results differ to a similar study that used intestinal slices of the rat for the toxicity ranking of five non-steroidal anti-inflammatory drugs (diflunisal $>$ diclofenac $=$ indomethacin $>$ Naproxen $>$ aspirin) for which a strong correlation was established between the published in vitro and in vivo data (Niu et al., 2014). This therefore would indicate that the vulture liver is either unable or poorly able to metabolise the NSAIDs in comparison to mammals. With this said, one of the problems with tissue cultures is that tissue from different individuals are known to have different hepatic enzyme concentrations, while different lobes of the liver may also differ in their metabolic capacity (Tottmar et al., 1973). Taking this into account we used tissue from the same donor animal and liver slices from the same lobe. To further demonstrate that limitation in metabolism played a role, the protein content in the liver was $3325 \mathrm{mg} / \mathrm{g}$, which was $24 \%$ lower than we predicted for an animal the size of the 
vulture $(8.7 \mathrm{~kg})$. While it may be argued that the use of mammalian data could have skewed the results, current allometric scaling indicates that mammals and bird can be grouped together (Cox et al., 2004). Based on the protein content, we are confident that the limitation in metabolic capacity is responsible for NSAIDs toxicity in old world vultures.

To further investigate the vulture restriction in hepatic capacity in comparison to mammals, we also evaluated the total amount of enzymes being expressed in the sampled bird. For this we used protein content as a surrogate, expressed in grams of albumin, as previously validated (Ronis and Walker, 1989). The actual enzyme capacity would then be a percentage of total protein content. Previous studies from nine mammalian species, showed that the cytochrome P450 content of liver microsomes was in the range of 48-114 mg CYP enzymes per gram of protein equivalents, while the CYP450 content of ten (10) Cape vulture liver slices was within the range of $12.2-26.5 \mathrm{mg}$ (result not shown) which is $10.7-55.2 \%$ lower than those in mammals. Nonetheless, the microsomal protein content of 10 Cape vulture liver slices was within the range of $2.78-12.31 \mathrm{mg} / \mathrm{g}$ liver weight compared to passeriformes (12-30.6 $\mathrm{mg} / \mathrm{g})$, galliformes $(10.8-27 \mathrm{mg} / \mathrm{g})$, pelecaniformes and Charadriformes (fish eaters) $(9-17.4 \mathrm{mg} / \mathrm{g})$ (Ronis and Walker, 1989). This would indicate that birds in general have a lower metabolic capacity than mammals. However, at this stage we were unable to determine how the vulture differs from other bird in their enzyme content, as thus far all other birds exposed to diclofenac have demonstrated a much quicker half-life of elimination than old world vulture species (Mompati, 2012) i.e. the evaluation of protein content while a surrogate for total enzyme expression, cannot differentiate between the ratio of enzymes being expressed. Hence it would be important to ascertain if all the mentioned bird groups do express the same number and ratio of enzyme or whether the vulture is deficient in the NSAIDs metabolising enzymes system. 
In man, it has been shown that diclofenac is metabolised by CYP2C9 while meloxicam is metabolised by both CYP2C9 and CYP3A4 (Bort et al., 1999,Busch et al., 1998,Smith and Jones, 1992,Chesne et al., 1998,Leemann et al., 1993). Interestingly, population based studies in people, have indicated that in meloxicam metabolism major pathway is via the involvement of the CYP3A4 enzymes, as persons with poorly functional CYP2C9 enzyme due to gene polymorphism, do not experience any altered pharmacokinetics (Chesne et al., 1998). Of the two, CYP2C9 is also responsible for the metabolism of most NSAIDs while CYP3A4 is known to metabolise $50 \%$ of clinically used drugs. In birds, at present the metabolic pathways for the various species and clades remains poorly studied, with much focus being on the chicken. Nonetheless, of these two enzyme systems, the CYP2 family were reported to be less represented in birds than mammals as evidenced by Western blotting and the response to inducers in the domestic chicken, Japanese quail, duck and cormorant (Ronis and Walker, 1989). Based on phenobarbital (PB) induction studies, PB caused the induction of only two CYP450 isoforms in the chicken compared to the rat and the rabbit which had four and five induced CYP isoforms respectively. Because of the low level of the inducible form of CYP450 in avian species, it is speculated that the CYP2 family are less represented (Althaus et al., 1979,Darby et al., 1986,Nebert and Gonzalez, 1987). With the CYP2 subfamily being known to be responsible for the metabolism of diclofenac in man and their lower representation in avian species, constraints at the level of this enzyme system may be reason for the vulture's susceptibility to diclofenac (Bort et al., 1999, Ronis and Walker, 1989,Rettie et al., 1992,Goldstein and de Morais, 1994).

Another important finding from this study was that while differing clearances were noted for ketoprofen and carprofen in comparison to diclofenac, the same was not the case for meloxicam. In an unexpected manner, the ex vivo clearance of diclofenac was not substantially lower to that of meloxicam (Fig.1). Firstly, this would indicate that the ex vivo 
liver slice model is not an appropriate model to predict the capability of old world vultures in metabolising NSAIDs as meloxicam is the most rapidly metabolised from all the evaluated drugs. More so, it is important to note that the liver tissue for the diclofenac and meloxicam also showed marked hepatic degeneration after a short incubation of only 6 hours, despite meloxicam being known to be safe in vivo, thereby indicating the role of adverse influence of cell death on drug metabolism and clearance. The exposure doses $(1 \mu \mathrm{M})$ used in this study were also relatively low compared to in vivo total in vivo exposure of $6.29 \mu \mathrm{g} / \mathrm{mL}^{*} \mathrm{~h}( \pm$ $20 \mu \mathrm{M}^{*} \mathrm{~h}$ ) at $2 \mathrm{mg} / \mathrm{kg}$ meloxicam. While we are unable to completely explain the reason for toxicity seen with meloxicam, we believe that this shows the importance of mean residence time in toxicity. When looking at the in vivo exposure $\left(3.524 \mu \mathrm{g} / \mathrm{mL}^{*} \mathrm{~h}\right)$, with a half-life of $0.42 \mathrm{~min}$, the liver was not exposed to high concentration of meloxicam for more than 2.1 hours, which represents five elimination half-lives. For this study, with exposure being 6 hours, the liver was being exposed to the meloxicam for 3 times as long. This also supports previous speculations that the rapid in vivo clearance of meloxicam played a major role in the safety of the molecule, as seen with ex vivo renal cultures by Naidoo and Swan, (2009) (Naidoo and Swan, 2009). From this study, they were able to demonstrate that renal tubular cell cultures were equally susceptible to diclofenac and meloxicam, with $40 \%$ cell death reported at $0.05 \mu \mathrm{Mol}$ of meloxicam after static exposure for 12 hours.

This study indicates that liver slices are not a useful tool to investigate the biotransformation of non-steroidal anti-inflammatory drugs in the vulture due to the toxicity of the drugs on the tissue as other factors such as direct cell toxicity can influence the results. Under in vivo conditions, the toxicity of the drug is likely mitigated by the ratio of total active metabolic cells in the whole organ in relation to drug plasma concentration, as well as by the rate of blood supply to the metabolically active tissues. It is also possible that clearance of non-metabolised meloxicam as seen in the cat, may also be involved. 


\section{Conflict of interest}

The authors declare that there are no conflicts of interest.

\section{Acknowledgement}

This research was funded by the National Research Foundation (NRF) of South Africa (Grant no 87772).

I also want to acknowledge the contribution of technical staff in the section of pharmacology and pathology at the Faculty of Veterinary Science for their invaluable support in making the project a success.

Contribution of Authors

Emmanuel Oluwasegun Adawaren was responsible for carrying out the research work, data analysis and study write-up.

Lilian Mukandiwa was responsibilities for study write-up.

Emmanuel Mfotie Njoya assisted with the liver slice culture assay and write-up of the study.

Lizette Bekker assisted with analytical evaluation of the drugs and study write-up.

Neil Duncan was responsible for the histopathological interpretation of the liver slides and write-up of the study.

Vinny Naidoo is the primary grant holder who conceptualizes the study and also was responsible for data analysis and study write-up. 


\section{References}

Althaus, F.R., Sinclair, J.F., Sinclair, P., Meyers, U.A., 1979. Drug-mediated induction of cytochrome(s) P-450 and drug metabolism in cultured hepatocytes maintained in chemically defined medium. J. Biol. Chem. 254, 2148-2153.

Angelov, I., Hashim, I., Oppel, S., 2013. Persistent electrocution mortality of Egyptian Vultures Neophron percnopterus over 28 years in East Africa. Bird Conservation International 23, 1-6.

Bort, R., Macé, K., Boobis, A., Gómez-Lechón, M., Pfeifer, A., Castell, J., 1999. Hepatic metabolism of diclofenac: role of human CYP in the minor oxidative pathways. Biochem. Pharmacol. 58, 787-796.

Boshoff, A.F., Minnie, J.C., Tambling, C.J., Michael, M.D., 2011. The impact of power linerelated mortality on the Cape Vulture Gyps coprotheres in a part of its range, with an emphasis on electrocution. Bird Conservation International 21, 311-327.

Bowden, C.G., Prakash, V., Ranade, S., Routh, A., Jakatt, R., Cuthbert, R., Rahmani, A.R., Green, R.E., Prakash, N., Parry-Jones, J., 2012. Conservation breeding for the future release of the critically endangered Asian Gyps vulturesprogress of the programme in south Asia and why it is so important. J. Bombay Nat. Hist. Soc. 109, 43-45.

Bradford, M.M., 1976. A rapid and sensitive method for the quantitation of microgram quantities of protein utilizing the principle of protein-dye binding. Anal. Biochem. 72, 248-254.

Burke, A., Smyth, E., FitzGerald, G.A., 2006. Analgesic-antipyretic agents; pharmacotherapy of gout. Goodman \& Gilman's the pharmacological basis of therapeutics 11, 671-715.

Busch, U., Schmid, J., Heinzel, G., Schmaus, H., Baierl, J., Huber, C., Roth, W., 1998. Pharmacokinetics of meloxicam in animals and the relevance to humans. Drug Metab. Dispos. 26, 576-584.

Chesne, C., Guyomard, C., Guillouzo, A., Schmid, J., Ludwig, E., Sauter, T., 1998. Metabolism of Meloxicam in human liver involves cytochromes P4502C9 and 3A4. Xenobiotica 28, 1-13.

Cox, S., Cottrell, M., Smith, L., Papich, M., Frazier, D., Bartges, J., 2004. Allometric analysis of ciprofloxacin and enrofloxacin pharmacokinetics across species. J. Vet. Pharmacol. Ther. 27, 139-146.

Darby, N.J., Lodola, A., Burnet, F., 1986. Testosterone metabolite profiles reveal differences in the spectrum of cytochrome P-450 isozymes induced by phenobarbitone, 2-acetylaminofluorene and 3-methylcholanthrene in the chick embryo liver. Biochem. Pharmacol. 35, 4073-4076.

de Graaf, I.A., Olinga, P., de Jager, M.H., Merema, M.T., de Kanter, R., van de Kerkhof, Esther G, Groothuis, G.M., 2010. Preparation and incubation of precision-cut liver and intestinal slices for application in drug metabolism and toxicity studies. Nature protocols 5, 1540-1551.

de Graaf, I.A., de Kanter, R., de Jager, M.H., Camacho, R., Langenkamp, E., van de Kerkhof, E.G., Groothuis, G.M., 2006. Empirical validation of a rat in vitro organ slice model as a tool for in vivo clearance prediction. Drug Metab. Dispos. 34, 591-599.

De Kanter, R., Monshouwer, M., Draaisma, A., De Jager, M., De Graaf, I., Proost, J., Meijer, D., Groothuis, G., 2004. Prediction of whole-body metabolic clearance of drugs through the combined use of slices from rat liver, lung, kidney, small intestine and colon. Xenobiotica 34, 229-241.

Fourie, T.A., 2015. The safety of carprofen, flunixin and phenylbutazone in the Cape Vulture (Gyps coprotheres)-a pilot study. University of Pretoria MSc dissertation.

Goldstein, J.A., de Morais, S.M., 1994. Biochemistry and molecular biology of the human CYP2C subfamily. Pharmacogenetics and Genomics 4, 285-300. 
Graaf, I.A.d., Groothuis, G.M., Olinga, P., 2007. Precision-cut tissue slices as a tool to predict metabolism of novel drugs, Expert Opin. Drug Metab. Toxicol. (2007) 3(6):879-898

Green, R.E., Newton, I., Shultz, S., Cunningham, A.A., Gilbert, M., Pain, D.J., Prakash, V., 2004. Diclofenac poisoning as a cause of vulture population declines across the Indian subcontinent. J. Appl. Ecol. 41, 793-800.

Grudé, P., Guittard, J., Garcia, C., Daoulas, I., Thoulon, F., Ebner, T., 2010. Excretion mass balance evaluation, metabolite profile analysis and metabolite identification in plasma and excreta after oral administration of [14C]-meloxicam to the male cat: preliminary study. J. Vet. Pharmacol. Ther. 33, 396-407.

Hilton-Taylor, C., Mittermeier, R.A., 2000. 2000 IUCN Red List of Threatened Species. IUCN Gland, Switzerland.

Houston, J.B., 1994. Utility of in vitro drug metabolism data in predicting in vivo metabolic clearance. Biochem. Pharmacol. 47, 1469-1479.

Hunter, R.P., Isaza, R., 2008. Concepts and issues with interspecies scaling in zoological pharmacology. Journal of Zoo and Wildlife Medicine 39, 517-526.

Kasperek, R., Zimmer, U., Jawie, W., Poleszak, E., 2015. Pharmacokinetics of diclofenac sodium and papaverine hydrochloride after oral administration of tablets to rabbits. Acta Pol. Pharm. 72, 527-538.

Kumar, S., Samuel, K., Subramanian, R., Braun, M.P., Stearns, R.A., Chiu, S.H., Evans, D.C., Baillie, T.A., 2002. Extrapolation of diclofenac clearance from in vitro microsomal metabolism data: role of acyl glucuronidation and sequential oxidative metabolism of the acyl glucuronide. J. Pharmacol. Exp. Ther. 303, 969-978.

Langdale, L.A., Kajikawa, O., Frevert, C., Liggitt, H.D., 2003. Sustained tolerance to lipopolysaccharide after liver ischemia-reperfusion injury. Shock 19, 553-558.

Lascelles, B.D.X., Court, M.H., Hardie, E.M., Robertson, S.A., 2007. Nonsteroidal antiinflammatory drugs in cats: a review. Veterinary anaesthesia and analgesia 34, 228-250.

Leemann, T., Transon, C., Dayer, P., 1993. Cytochrome P450TB (CYP2C): a major monooxygenase catalyzing diclofenac 4'-hydroxylation in human liver. Life Sci. 52, 29-34.

Mahmood, I., 2007. Application of allometric principles for the prediction of pharmacokinetics in human and veterinary drug development. Adv. Drug Deliv. Rev. 59, 1177-1192.

MaMing, R., Xu, G., 2015. Status and threats to vultures in China. Vultures News 68, 3-24.

Markandya, A., Taylor, T., Longo, A., Murty, M., Murty, S., Dhavala, K., 2008. Counting the cost of vulture decline-An appraisal of the human health and other benefits of vultures in India. Ecol. Econ. 67, 194-204.

Martinez, C., Alonso, L., 2014. Exposure and Effects of Oil Sands-Related Emissions on Wild Birds .

Mompati, K.F., 2012. The insensitivity of the crow (Corvus albus) to diclofenac toxicity. University of Pretoria MSc dissertation.

Naidoo, V., Duncan, N., Bekker, L., Swan, G., 2007. Validating the domestic fowl as a model to investigate the pathophysiology of diclofenac in Gyps vultures. Environ. Toxicol. Pharmacol. 24, 260-266.

Naidoo, V., Taggart, M., Duncan, N., Wolter, K., Chipangura, J., Green, R., Galligan, T., 2017. The use of toxicokinetics and exposure studies to show that carprofen in cattle tissue could lead to secondary toxicity and death in wild vultures. Chemosphere . 
Naidoo, V., Wolter, K., Cromarty, A., Bartels, P., Bekker, L., McGaw, L., Taggart, M., Cuthbert, R., Swan, G., 2008. The pharmacokinetics of meloxicam in vultures. J. Vet. Pharmacol. Ther. 31, 128-134.

Naidoo, V., Wolter, K., Cuthbert, R., Duncan, N., 2009. Veterinary diclofenac threatens Africa's endangered vulture species. Regulatory toxicology and pharmacology 53, 205-208.

Naidoo, V., Swan, G.E., 2009. Diclofenac toxicity in Gyps vulture is associated with decreased uric acid excretion and not renal portal vasoconstriction. Comparative Biochemistry and Physiology Part C: Toxicology \& Pharmacology 149, 269-274.

Naidoo, V., Venter, L., Wolter, K., Taggart, M., Cuthbert, R., 2010. The toxicokinetics of ketoprofen in Gyps coprotheres: toxicity due to zero-order metabolism. Arch. Toxicol. 84, 761766.

Naidoo, V., Wolter, K., Espie, I., Kotze, A., 2011. Vulture rescue and rehabilitation in South Africa: An urban perspective. J. S. Afr. Vet. Assoc. 82, 24-31.

Naidoo, V., Wolter, K., Botha, C.J., 2017. Lead ingestion as a potential contributing factor to the decline in vulture populations in southern Africa. Environ. Res. 152, 150-156.

Naidoo, V., Wolter, K., Cromarty, D., Diekmann, M., Duncan, N., Meharg, A.A., Taggart, M.A., Venter, L., Cuthbert, R., 2010. Toxicity of non-steroidal anti-inflammatory drugs to Gyps vultures: a new threat from ketoprofen. Biol. Lett. 6, 339-341.

Naidoo, V., Mompati, K.F., Duncan, N., Taggart, M.A., 2011. The Pied Crow (Corvus Albus) is Insensitive to Diclofenac at Concentrations Present in Carrion. J. Wildl. Dis. 47, 936-944.

Nebert, D.W., Gonzalez, F.J., 1987. P450 genes: structure, evolution, and regulation. Annu. Rev. Biochem. 56, 945-993.

Niu, X., de Graaf, I.A., van der Bij, Hendrik A, Groothuis, G.M., 2014. Precision cut intestinal slices are an appropriate ex vivo model to study NSAID-induced intestinal toxicity in rats. Toxicology in Vitro 28, 1296-1305.

Oaks, J.L., Gilbert, M., Virani, M.Z., Watson, R.T., Meteyer, C.U., Rideout, B.A., Shivaprasad, H., Ahmed, S., Chaudhry, M.J.I., Arshad, M., 2004. Diclofenac residues as the cause of vulture population decline in Pakistan. Nature 427, 630-633.

Ogada, D.L., Keesing, F., Virani, M.Z., 2012. Dropping dead: causes and consequences of vulture population declines worldwide. Ann. N. Y. Acad. Sci. 1249, 57-71.

Papp, Z., Bortolotti, G., Smits, J., 2005. Organochlorine contamination and physiological responses in nestling tree swallows in Point Pelee National Park, Canada. Arch. Environ. Contam. Toxicol. 49, 563-568.

Prakash, V., Green, R., Pain, D., Ranade, S., Saravanan, S., Prakash, N., Venkitachalam, R., Cuthbert, R., Rahmani, A., Cunningham, A., 2007. Recent changes in populations of resident Gyps vultures in India. J. Bombay Nat. Hist. Soc. 104, 129-135.

Prism, G., 2014. version 6.0 e. GraphPad Software .

Rane, A., Wilkinson, G.R., Shand, D.G., 1977. Prediction of hepatic extraction ratio from in vitro measurement of intrinsic clearance. J. Pharmacol. Exp. Ther. 200, 420-424.

Rattner, B.A., Whitehead, M.A., Gasper, G., Meteyer, C.U., Link, W.A., Taggart, M.A., Meharg, A.A., Pattee, O.H., Pain, D.J., 2008. Apparent tolerance of turkey vultures (Cathartes aura) to the non-steroidal anti-inflammatory drug diclofenac. Environmental Toxicology and Chemistry 27, 2341-2345.

Rettie, A.E., Korzekwa, K.R., Kunze, K.L., Lawrence, R.F., Eddy, A.C., Aoyama, T., Gelboin, H.V., Gonzalez, F.J., Trager, W.F., 1992. Hydroxylation of warfarin by human cDNA-expressed 
cytochrome P-450: a role for P-4502C9 in the etiology of (S)-warfarin-drug interactions. Chem. Res. Toxicol. 5, 54-59.

Riviere, J., Martin-Jimenez, T., Sundlof, S., Craigmill, A., 1997. Interspecies allometric analysis of the comparative pharmacokinetics of 44 drugs across veterinary and laboratory animal species. J. Vet. Pharmacol. Ther. 20, 453-463.

Ronis, M.J., Walker, C.H., 1989. The microsomal monooxygenase of birds. Reviews in biochemical toxicology (USA) .

Sarans, R.P., Purohit, A., 2012. Eco-transformation and electrocution. A major concern for the decline in vulture population in and around Jodhpur. International journal of conservation science 3.

Save, 2014. Saving Asian Vultures from Extinction. www.savevulture.org/save_solution_breedingcentres.html 2/06/2015.

Scott, S., Sangkuhl, K., Gardner, E., Stein, C., Hulot, J., Johnson, J., Roden, D., Klein, T., Shuldiner, A., 2011. Clinical Pharmacogenetics Implementation Consortium guidelines for cytochrome P450-2C19 (CYP2C19) genotype and clopidogrel therapy. CliniCal pharmaCology \& TherapeuTiCs 90, 328-332.

Scully, L., Clarke, D., Barr, R., 1993. Diclofenac induced hepatitis. Dig. Dis. Sci. 38, 744-751.

Shultz, S., Baral, H.S., Charman, S., Cunningham, A.A., Das, D., Ghalsasi, G.R., Goudar, M.S., Green, R.E., Jones, A., Nighot, P., Pain, D.J., Prakash, V., 2004. Diclofenac poisoning is widespread in declining vulture populations across the Indian subcontinent. Proceedings of the Royal Society B-Biological Sciences 271, S458-S460.

Smith, D.A., Jones, B.C., 1992. Speculations on the substrate structure-activity relationship (SSAR) of cytochrome P450 enzymes. Biochem. Pharmacol. 44, 2089-2098.

Swan, G., Naidoo, V., Cuthbert, R., Green, R.E., Pain, D.J., Swarup, D., Prakash, V., Taggart, M., Bekker, L., Das, D., 2006a. Removing the threat of diclofenac to critically endangered Asian vultures. PLoS biology 4, e66.

Swan, G.E., Cuthbert, R., Quevedo, M., Green, R.E., Pain, D.J., Bartels, P., Cunningham, A.A., Duncan, N., Meharg, A.A., Oaks, J.L., Parry-Jones, J., Shultz, S., Taggart, M.A., Verdoorn, G., Wolter, K., 2006b. Toxicity of diclofenac to Gyps vultures. Biol. Lett. 2, 279-282.

t Hart, N.A., van der Plaats, A., Faber, A., Leuvenink, H.G., Olinga, P., Wiersema-Buist, J., Verkerke, G.J., Rakhorst, G., Ploeg, R.J., 2005. Oxygenation during hypothermic rat liver preservation: an in vitro slice study to demonstrate beneficial or toxic oxygenation effects. Liver transplantation 11, 1403-1411.

Tottmar, S.O., Pettersson, H., Kiessling, K.H., 1973. The subcellular distribution and properties of aldehyde dehydrogenases in rat liver. Biochem. J. 135, 577-586.

Vijaikumar, M., Thappa, D.M., Karthikeyan, K., 2002. Cutaneous anthrax: an endemic outbreak in south India. J. Trop. Pediatr. 48, 225-226.

Virani, M.Z., Kendall, C., Njoroge, P., Thomsett, S., 2011. Major declines in the abundance of vultures and other scavenging raptors in and around the Masai Mara ecosystem, Kenya. Biol. Conserv. 144, 746-752.

Watanabe, K.P., Kawai, Y.K., Ikenaka, Y., Kawata, M., Ikushiro, S., Sakaki, T., Ishizuka, M., 2013. Avian cytochrome P450 (CYP) 1-3 family genes: isoforms, evolutionary relationships, and mRNA expression in chicken liver. PloS one 8.

Yan, Z., Caldwell, G.W., 2001. Metabolism profiling, and cytochrome P450 inhibition \& induction in drug discovery. Current topics in medicinal chemistry 1, 403-425. 